УДК 002.2-028.27:02](477)

Спірін Олег Михайлович, доктор педагогічних наук, головний науковий співробітник, Інститут інформаційних технологій і засобів навчання НАПН України, м. Київ, е-mail: Oleg.Spirin@gmail.com

Іванова Світлана Миколаївна, науковий співробітник Інституту інформаційних технологій і засобів навчання НАПН України, м. Київ, e-mail: iv-svetlana@ yandex.ru Новицький Олександр Вадимович, науковий співробітник, Інститут інформаційних технологій і засобів навчання НАПН України, м. Київ, e-mail: alex.googl@gmail.com

\title{
КОНЦЕПТУАЛЬНІ ЗАСАДИ ПОБУДОВИ МЕРЕЖІ ЕЛЕКТРОННИХ БІБЛІОТЕК НАЦІОНАЛЬНОЇ АКАДЕМЇ̈ ПЕДАГОГІЧНИХ НАУК УКРАЇНИ
}

\section{Анотація}

У статті визначаються попередні умови проектування мережі електронних бібліотек Національної академії педагогічних наук України, основні компоненти i базові сервіси для створення мережі електронних бібліотек (ЕБ). Аналізуються основні підходи щодо формування інформаційних ресурсів ЕБ; виділяються основні організаційні засади створення й адміністрування ЕБ.

Пропонуються методологія наповнення ЕБ ресурсами й підходи щодо розроблення типових проектних рішень для побудови ЕБ. Зазначається, що мережа електронних бібліотек дозволить змінити принцип інформаційного обслуговування користувачів та по-новому організувати робоче місце науковця.

Ключові слова: електронна бібліотека, мережа електронних бібліотек, формування інформаційних ресурсів.

Актуальність. У процесі перехідного періоду від індустріального суспільства до суспільства знань важливим завданням постає створення мережного розподіленого середовища для забезпечення доступу до ресурсів бібліотек, архівів, музеїв та інших інформаційних систем у галузі науки й освіти. Одним із пріоритетів розвитку інформаційного суспільства в Україні є забезпечення вільного доступу до бібліотек різних галузей. 
Особливістю сучасного етапу розвитку суспільства є те, що відомості існують як в традиційній друкованій, так і в електронній формі. Забезпечення публічного, зокрема, віддаленого, доступу користувачів до електронних інформаційних ресурсів (ЕIP) стає одним 3 першочергових завдань інформаційного обслуговування науки, освіти і культури, у зв'язку з цим істотно змінюється роль і функції такого соціального інституту, як бібліотека.

Особливу роль у розширенні доступу до відомостей і даних відіграють електронні бібліотеки, що забезпечують подання інформаційних ресурсів (IP) в електронному вигляді, віддалений доступ до них з використанням інформаційнокомунікаційних технологій (IКT). Вони $є$ складовою науково-освітнього інформаційного простору, а також національного бібліотечно-інформаційного фонду країни.

Актуальною є проблема створення мережі електронних бібліотек навчальних і наукових установ. Вона значно підвищить рівень надання фахівцям бібліотечних послуг, а саме:

- сприятиме вільному доступу до наявних EIP в мережі Інтернет, насамперед до бібліотек і періодичних видань, а також до зарубіжних електронних ресурсів;

- забезпечуватиме якісно новий рівень задоволення інформаційних потреб науковців завдяки використанню IКТ.

Роботи з розвитку електронних бібліотек, створення мереж електронних бібліотек і формування інформаційних наукових і освітніх ресурсів передбачені у Законі України «Про Національну програму інформатизації», де затверджена Державна програма «Електронна бібліотека» [2]. У Законі України «Про Основні засади розвитку інформаційного суспільства в Україні на 2007-2015 роки» від 09.01.2007 року № 537-V [3] також виокремлюється необхідність вирішення питання електронної бібліотеки. Постановою Кабінету Міністрів України від 17 серпня 2011 р. № 956 було затверджено Концепцію Державної цільової національно-культурної програми створення єдиної інформаційної бібліотечної системи «Бібліотека-XXI». Метою Програми $\epsilon$ «підвищення ефективності використання, забезпечення доступності документів, які зберігаються у бібліотечних, архівних та музейних фондах» [5]. 
У наукових установах і навчальних закладах НАПН України функціонують бібліотеки, що переважно використовують традиційні технології. Необхідність підвищення ефективності інформаційного забезпечення наукової й освітньої діяльності, інтеграції освіти і науки в науково-світовий інформаційний простір вимагають, а розвиток інформаційно-комунікаційних технологій дозволяє, суттєво вдосконалити бібліотечну діяльність на основі застосування ЕБ і розподілених бібліотечних інформаційних мереж. Сучасні наукові дослідження потребують інтеграції гетерогенної інформації з різних джерел. Тому під час проектування мережі ЕБ постає проблема побудови моделі, яка б найбільш відображала вимоги та потреби наукової спільноти.

Метою статті $\epsilon$ визначення попередніх умов проектування, основних компонентів і базових сервісів для створення мережі електронних бібліотек Національної академії педагогічних наук України, основних підходів щодо формування інформаційних ресурсів ЕБ; організаційних засад створення та адміністрування ЕБ.

Виклад основного матеріалу. Метою створення мережі електронних бібліотек Національної академії педагогічних наук України $є$ формування науково-освітніх ресурсів та забезпечення користувачів Інтернет-доступом до них.

Передбачається створення єдиного наукового інформаційного простору електронних бібліотек установ НАПН України, який включає до себе мережу електронних бібліотек. Мережа складається із серверів (вузлів) електронних бібліотек, а також їі центрального сервера (центрального вузла). На цей сервер покладені завдання підтримки роботи віртуальних бібліотек, а також функції керування мережею електронних бібліотек установ НАПН України. Віртуальні бібліотеки є незалежними складовими частинами центрального бібліотечного сервера мережі електронних бібліотек, які розмежовані правами доступу й об'єднані єдиним каталогом електронних ресурсів і користувачів мережі.

Кожній установі НАПН України за необхідністю може бути виділена робоча область (віртуальна бібліотека на сервері Інституту інформаційних технологій i засобів навчання), яку вони заповнять своїми інформаційними ресурсами. Така робоча область включає сегмент єдиного каталогу мережі електронних бібліотек 
установ НАПН України, сегмент єдиного каталогу цієї мережі, а також необхідні сервіси керування віртуальною бібліотекою.

Завдання, що будуть розв'язані за умови створення мережі ЕБ:

1) досягнення якісно нового рівня, повноти й оперативності задоволення інформаційних потреб науковців НАПН України за рахунок використання нових інформаційних технологій з метою підвищення якості наукових досліджень;

2) підвищення ефективності використання наявних наукових інформаційних ресурсів НАПН України за рахунок створення якісно нового інформаційного середовища;

3) найефективніше використання можливостей сучасних інформаційних технологій;

4) оперативне інформування наукової громадськості про результати наукової діяльності в НАПН України;

5) координація наукової діяльності організацій НАПН України в організації інформаційного обслуговування співробітників НАПН України;

6) входження наукової громадськості НАПН України у світову інформаційну громадськість і світовий інформаційний ринок;

7) збереження і подальший розвиток наукових зв'язків;

8) інформування наукової громадськості про наукові дослідження і розробки в закладах та установах НАПН України.

Слід виокремити основні принципи, що мають бути враховані під час створення мережі електронних бібліотек.

Багатофункціональність. Мережа ЕБ НАПН України як джерело відомостей має розв’ язувати різні науково-освітні завдання, зокрема:

- інформаційні, для задоволення потреби наукових співробітників НАПН України й інших наукових і навчальних закладів України і світу у різноманітних наукових відомостей та даних;

- наукові, які спрямовані на сприяння в проведенні наукових досліджень науковцями і фахівцями через надання наукових відомостей;

- освітні, для підтримки належного освітнього рівня шляхом надання доступу до відповідних матеріалів; 
- довідкові, для надання різних наукових довідкових матеріалів, зокрема автореферати, підручники, монографії, довідники та ін.;

- просвітницькі, для популяризації вітчизняних наукових досягнень, презентації наукових установ і науковців;

- фондостворюючі, для забезпечення збереження наукового фонду України.

Цілісність. Передбачає створення цілісної самодостатньої ресурсної структури як складової інформаційної системи НАПН України.

Численність науково-освітніх відомостей. Мережа ЕБ НАПН України повинна містити численні різноманітні науково-освітні відомості. Насамперед, до них відносяться: періодичні видання, препринти, наукові статті, монографії, реферати дисертацій і тексти дисертацій, звіти про науково-дослідну роботу, науково-довідкова інформація тощо. Перелік не є фіксованим і повинен легко розширюватися в мережі ЕБ. Хронологічні рамки для документів, що включаються в мережу ЕБ, не встановлюються.

Централізованість. Інформаційні ресурси повинні організовуватися за принципом централізованої бази даних. Це означає, що будь-які інформаційні ресурси будуть зберігатися централізовано.

Принцип відкритих систем. Створення середовища, що містить програмні, апаратні засоби, служби зв’язку, інтерфейси, формати даних та протоколи, які у своїй основі мають доступні й загальновизнані стандарти, що забезпечують перенос, взаємодію та масштабованість застосувань та даних.

Демократичність. Забезпечення рівних можливостей користувачів мережі ЕБ НАПН України для отримання відомостей та даних.

Відповідність сучасному рівню розвитку інформаційно-комунікаційних технологій. Основні проектні рішення створення мережі ЕБ НАПН України грунтуються на використанні сучасного програмного забезпечення Eprints, операційної системи Linux, засадах технології Web.

Доступність. Мережа ЕБ НАПН України повинна бути максимально доступною для вчених і освітян. Інформаційні ресурси за можливості повинні бути максимально відкритими для їх використання.

Розвиненість пошукових засобів. Відмінною рисою ЕБ НАПН України $є$ можливість одночасного використання різних пошукових механізмів i засобів 
доступу до вітчизняних баз електронних документів. Пошукові засоби повинні бути організовані так, щоб їхні можливості були прозорими щодо розподілу інформаційних ресурсів за різними сайтами i базами даних та можливої неоднорідності форматів даних. Мають підтримувати різні механізми інформаційного пошуку. Пошукова мова повинна мати достатню повноту для знаходження адекватних інформаційних ресурсів. Не менш важливим є розв'язання проблеми подання різнорідних відомостей i даних у зручному вигляді для кінцевого користувача.

Розвиток співробітництва. Встановлення нових зв'язків 3 науковцями, педагогами, освітніми та науковими установами й організаціями 3 метою накопичення і передавання професійного досвіду та набуття знань.

Функціональна стандартизація. Особлива увага у створенні електронної бібліотеки приділяється узгодженню використовуваних стандартів з урахуванням прийнятих міжнародних стандартів з організації і ведення електронних бібліотек.

Правове і нормативне забезпечення. Буде розроблена нормативна база функціонування мережі ЕБ НАПН України, зокрема, у тому числі сформульовані пропозиції з удосконалення діючих чи прийняття нових нормативних актів НАПН України. Має бути визначений порядок взаємодії різних категорій учасників НЕБ (наукова електронна бібліотека), їхні права та обов'язки, вирішені питання авторського права й інших форм інтелектуальної власності. Має бути розроблений комплекс організаційних, нормативно-технічних документів, що регламентують створення і використання НЕБ, а також фінансових аспектів їх функціонування.

Проектування мережі електронних бібліотек технологічно й організаційно об'єднує бібліотечні комплекси наукових установ і навчальних закладів НАПН України, тому має свої особливості та відмінності.

Згідно Концепції Державної цільової національно-культурної програми створення єдиної інформаційної бібліотечної системи «Бібліотека-XXI» [4] визначені вихідні дані для проектування мережі електронних бібліотек НАПН України, зокрема таке.

1. Наявність розподіленої системи електронних каталогів та інформаційних ресурсів власної генерації, сформованих під управлінням кількох різних 
автоматизованих бібліотечно-інформаційних систем (АБІС) і представлених в Інтернеті у вигляді бібліотечних сайтів.

2. Нерівномірний розвиток рівня надання доступу до електронних ресурсів в бібліотеках.

3. Бібліографічні інформаційні ресурси й електронні документи зберігаються розподілено у файлових системах комп’ютерів бібліотек.

4. Наявність великої кількості онлайнових інформаційних ресурсів різної тематичної спрямованості, одержуваних з Інтернету. Постачальники ресурсів не пов'язані єдиною пошуковою системою, а на сайтах бібліотек іноді подаються у вигляді списку.

5. Весь навчально-методичний комплекс дисциплін навчальних закладів НАПН України - багаторівневих i багатозв'язних електронних документів, необхідних для впровадження сучасних технологій навчання, зокрема дистанційного, не організований в єдиний інформаційний ресурс, доступ 3 Інтернету до нього ускладнений або іноді відсутній.

6. Відсутність доступу до повнотекстових ресурсів, які продукуються в установах Академії, що призводить до низьких рівнів індекс-цитувань статей, особливо зарубіжними авторами. Ця проблема виникає внаслідок відсутності середовища, до якого такі ресурси можна вносити та їх опрацьовувати.

Саме для розв'язання останньої проблеми, яка є найголовнішою, пропонується впровадити в рамках НАПН України мережу електронних бібліотек

У процесі виконання роботи, на підставі аналізу результатів проектування мережі електронних бібліотек, інформаційно-процесуального навантаження у вузлах мережі й комунікаційних каналах проектується модель корпоративної автоматизованої інформаційної розподіленої бібліотечної мережі установ НАПН України [7]. Ця модель повинна описати архітектуру будови мережі, іiі структуру i склад, що розподілені у просторі й за процесорною потужністю іiі комп'ютерних вузлів, де має опрацьовуватись бібліотечні відомості та дані, забезпечуватись їх накопичення, зберігання, актуалізація та доступ до них користувачів.

За результатами використання спроектованої корпоративної розподіленої мережі електронних бібліотек НАПН України, іiі вузли будуть оснащатися відповідними програмно-технічними засобами з урахуванням вимог щодо пропускної 
спроможності комунікаційних каналів, порядку і характеру взаємодії засобів мережі 3 різними категоріями іï користувачів. Програмне забезпечення супроводжується відповідною документацією для користувачів і адміністраторів. Під час реалізації проекту значна увага буде приділена семантичній інтеграції ресурсів. Для кожного ресурсу буде автоматизовано побудована формальна семантична модель метаданих у вигляді RDF графу з використанням технології RDFa. Це забезпечить якісне подання й уніфікований доступ до електронних ресурсів установ у мережі Інтернет, в освітньо-наукових базах і пошукових системах.

Дослідження передбачає створення інтегрованого середовища управління електронними бібліотеками. У даному середовищі будуть виділятися віртуальні робочі області для створення й управління електронними бібліотеками установ НАПН України.

Основна увага буде приділятися інтеграції інформації і розробці уніфікованих сервісів. Електронна бібліотека буде знаходитися в рамках віртуальної робочої області. Тобто, ця система є Системою Управління Електронними Бібліотеками (СУЕБ). У свою чергу кожен інформаційний ресурс буде мати свою семантичну модель на рівні метаданих.

1. У проектних рішеннях використовуються технології відкритих систем, відкриті мережні протоколи, перспективні схеми і стандарти, що постійно оновлюються.

2. Усі проектні рішення мають бути типізовані й орієнтуватися на міжбібліотечну співпрацю і кооперацію відповідно до правил міжнародного інформаційного обміну.

3. У проекті необхідно максимально використовувати передовий досвід реалізації мережі електронних бібліотек в інших організаціях у цілому або у вигляді окремих функціональних складових.

4. Проект мережі електронних бібліотек створюється за модульною схемою. Вся система розбивається на модулі - підсистеми. Підсистеми виділяються за принципом функціональної спільності і подібності технологій. Такий принцип організації дозволяє розподілити проектування мережі електронних бібліотек між спеціалістами різного профілю, а згодом забезпечує можливість 
заміни окремих модулів або їх зміну з метою вдосконалення функціонала мережі або іiі адаптації до нових умов.

5. У проекті необхідно передбачити поетапне впровадження підсистем та їхніх функціональних складових, а також можливість масштабування, розвитку та доопрацювання рішень у кожній з наявних підсистем.

6. Технологічна інтеграція - єдність для всієї системи технології створення, оновлення, збереження і використання інформаційних ресурсів, зокрема, одноразове опрацювання документів поряд з багаторазовим і багатоцільовим їх використанням.

7. Корпоративність - дотримання принципів корпоративної взаємодії освітніх і наукових бібліотек i забезпечення органічного вбудовування мережі електронних бібліотек НАПН України в інформаційно-освітнє середовище України.

8. Регламентованість усіх етапів функціонування мережі електронних бібліотек стандартами, маршрутними та поопераційними технологіями, нормативами на ресурсні та часові показники та ін.

9. Пріоритет економічної доцільності - вибір таких проектних рішень, які за умови досягнення поставлених цілей і завдань забезпечують мінімізацію витрат фінансових, матеріальних і кадрових ресурсів.

10. Максимальне використання готових рішень для скорочення вартості i термінів розробки й упровадження, а також зменшення помилок проектування. Усі оригінальні розробки в функціоналі майбутньої системи пов'язані з інтеграцією і взаємодією готових блоків системи між собою.

11. Дотримання принципу спадкоємності - проект передбачається створювати на основі вже працюючого функціонала 3 максимально повним використанням наявних рішень.

Мережа електронних бібліотек НАПН України - це сукупність електронних науково-освітніх бібліотек установ, взаємопов'язаних цільовим призначенням, складом користувачів і політикою комплектування фондів наукової, навчальної літератури та нормативно-технічої документації на всіх видах носіїв інформації, що мають відбивати розвиток психолого-педагогічної науки в Україні та за кордоном і створювати єдині розподілені та взаємовикористовувані інформаційно-бібліотечні 
ресурси НАПН України. Головним завданням кожної бібліотеки і системи у цілому є бібліотечно-інформаційне забезпечення фундаментальних і прикладних наукових досліджень, насамперед, психолого-педагогічних, загальнодержавних науковоосвітніх програм та проектів.

Однією 3 головних особливостей функціонування мережі електронних бібліотек є формування інформаційних ресурсів (IP). Інформаційні ресурси - це ядро мережі ЕБ НАПН України. Інформаційні ресурси в окремих випадках формуються оцифруванням існуючих документів на паперових носіях чи, як правило, використанням документів на магнітних носіях. Вихідні електронні документи можуть бути різних форматів, що представляють текстову інформацію, графічну, аудіо- і відеоінформацію.

Електронні ресурси установ НАПН України формуються в 2 етапи:

1. Самоархівування.

2. Формування цифрового контенту.

Наповнення електронними ресурсами мережі ЕБ НАПН України здійснюватиметься за принципами самоархівування та централізованого введення документів. Лише після того, як буде досягнуто 100 \% щорічного самоархівування власних наукових результатів організації, можна спрямовувати свої зусилля на інші цифрові цілі [1]. Процес формування контенту ЕБ передбачає, що матеріали для публікування в мережі ЕБ НАПН України, насамперед, мають готуватися авторами за результатами разових та періодичних регулярних (квартальних, піврічних, щорічних, тощо) звітів, тобто всі ресурси, згідно вищенаведеного переліку, повинні бути внесені до ЕБ НАПН України в повнотекстовому вигляді [6]. Такі матеріали самостійно депонуються автором або відповідальною особою, за принципом самоархівування. Поточні загальні результати (автореферати дисертацій, що захищалися у спеціалізованій раді установи або працівниками; матеріали конференцій, тези наукових доповідей та ін.), вносяться до мережі ЕБ НАПН України розподілено або відповідальною особою.

Мережу ЕБ НАПН України рекомендується створити відповідно до Ініціативи Відкритого Доступу (Open Archives Initiative) [8].

Централізоване введення документів. Тільки певний користувач або група користувачів, яка належать колективу, що використовує ЕБ, мають право вносити 
документи. Наприклад, якщо створюється ЕБ журналу, то таке право надається конкретній особі(ам) зі складу редакції журналу, яка має права адміністратора.

Відкрите введення документів. Це альтернативний варіант попередньому. Будь-яка людина може додати в ЕБ документ. У таких випадках, як правило, у складі служби експлуатації ЕБ $є$ фахівець (група фахівців), так званий редактор, відповідальний за перевірку якості і правильності оформлення введених документів. Усі введені документи обов'язково проходять редагування і тільки після їх схвалення редактором потрапляють в архів ЕБ. У випадку невідповідності прийнятим в ЕБ вимогам документи можуть бути повернуті відправнику на доопрацювання або відхилені до прийому.

Розподілене введення документів. Використовується за наявності колекцій або деяких інших сукупностей документів. Для кожної колекції виділяється група осіб, які володіють правом введення. У цьому випадку редактор перевіряє коректність введених документів. Системи подібного роду найкраще підходять тоді, коли ЕБ створюється в організаціях зі складною ієрархічною структурою, наприклад у ВНЗ.

\section{Організаційні засади створення ЕБ НАПН України}

Управління інформаційними ресурсами починається 3 того моменту, коли автор ресурсу направляє текст і дані про нього у сховище (репозиторій). Водночас відбувається автоматична реєстрація ресурсу в системі, автоматичне індексування, i дані стають доступними для пошуку.

Підготовка й електронне опрацювання документів здійснюється авторами та редакторами ЕБ, які виділяються зі штату бібліотеки (установи), що бере участь у проекті. Проект планується втілювати централізовано, тобто на базі IITЗН будується єдине сховище, у якому виділяються робочі області колекцій для кожної з установ НАПН України.

Мережа бібліотек НАПН України включає:

- електронну наукову бібліотеку Інституту інформаційних технологій і засобів навчання НАПН України (режим доступу: lib.iitta.gov.ua);

- бібліотеки науково-дослідних установ НАПН України.

Щоб уникнути проблем 3 дотриманням законодавства 3 авторського права, необхідною умовою є згода автора, який депонує свій ресурс до ЕБ, з умовами, на яких цей ресурс буде публікуватися в ЕБ. 


\section{Адміністрування бібліотеки}

Адміністрування - це центральна функція, що визначає ефективність ЕБ. До функцій адміністратора належить:

- встановлення конфігурації й налагодження ЕБ;

- забезпечення цілісності й безпеки ЕБ;

- надання користувачам прав доступу;

- аналіз роботи ЕБ і підтримка необхідної ефективності і якості функціонування ЕБ;

- включення ЕБ в інші інтеграційні системи інформаційного обслуговування користувачів.

\section{Очікувані результати.}

Дослідний зразок програмного комплексу сервера мережі електронних бібліотек матиме такі показники:

- інтеграція інформаційних ресурсів за допомогою Intranet/Internet технології;

- доступ з Internet до бібліографічної інформації інших бібліотечних систем за протоколом ОАI-PMH;

- обслуговування запитів на інформаційні ресурси бібліотек та пошук необхідної інформації;

- підтримка корпоративної каталогізації і зведеного електронного каталогу бібліотек;

- підтримка обробки бібліографічних записів у форматі Dublin Core;

- єдиний інтерфейс та множину сервісів для роботи з мережею;

- підтримка технології семантичної розмітки RDFa;

- чотирирівнева модель доступу до бібліотеки, включаючи анонімний вільний доступ;

- багатомовний інтерфейс;

- управління віртуальними організаціями та робочими областями;

- інтегрований пошук по різноманітних полях метаданих, та повнотекстовий пошук;

- навігація по електронній бібліотеці;

- робота з ресурсами ЕБ за допомогою Semantic Web браузерів; 
- підтримка семантичного опису інформаційних ресурсів на основі технологіï Semantic Web;

- сервісно-орієнтований підхід до побудови програмного забезпечення;

- захищеність конфіденційної інформації, або такої що не підлягає розголошенню завдяки підтримки протоколу http;

- аналітична інформація індекс-цитувань кожного інформаційного pecypcy.

Орієнтовні обсяги впровадження визначаються такими показниками:

- кожна з установ і навчальних закладів НАПН України матиме умови для створення електронної бібліотеки, що об’ єднані в мережу ЕБ НАПН України;

- орієнтовний обсяг даних, що потенційно може бути опрацьований в мережі електронних бібліотек - понад 1 млн. документів;

- орієнтовна кількість одиниць бібліографічних записів, які будуть створені в мережі, — понад 3000;

- орієнтовна кількість користувачів системи з боку НАПН України - 1300 науковців, понад 600 аспірантів і докторантів та 1200 осіб, що навчаються;

- орієнтовна кількість читачів мережі — до 100000 на рік.

Висновки. Застосування мережі електронних бібліотек дозволить розв'язати проблему збереження значних обсягів наукових відомостей, здійснити інтеграцію роз'єднаних інформаційних ресурсів, а також надасть можливість збереження раніше не збережених даних, що взагалі втрачаються (лабораторних журналів, фотографій, зображень, звуків, відеоінформації тощо).

Будуть скорочені витрати з численного дублювання створюваних локальних баз даних і інформаційних систем. У результаті реалізації проекту буде розвинута наявна інфраструктура для генерації, організації, пошуку і передавання різнорідних електронних даних від інформаційних центрів-виробників до кінцевого користувача.

Мережа електронних бібліотек НАПН України дозволить докорінно змінити сам принцип інформаційного обслуговування користувачів: звертаючись до системи, вони будуть одержувати не лише посилання (бібліографію чи реферат) на наявний електронний документ, але і сам документ (повну копію оригінальної статті, автореферат дисертації, графічний образ картини чи технічного креслення, відеозапис проведеного дослідження тощо). 
Створення мережі електронних бібліотек дозволить по-новому організувати робоче місце науковця шляхом реалізації можливості колективної роботи і навчання, створення колективних віртуальних середовищ. Поряд з тим буде знижено вартість наукових досліджень за рахунок колективного використання інформаційних ресурсів.

Побудова мережі ЕБ сприятиме розв'язанню найважливішого соціальнозначущого завдання - представлення багатої науково-педагогічної спадщини України у світовому інформаційному просторі.

\section{Список використаних джерел}

1. Вопросы и ответы о самоархивировании [Электронный ресурс] // Веб-сайт "СОЦИОНЕТ". - 2000-2009. — Режим доступа : http://socionet.ru/docs/self-archivingFAQ-ru.htm\#33.DigitaLibidoo. - Заголовок с экрана.

2. Закон України «Про Національну програму інформатизації» № 74/98 ВР від 04.02.1998, остання редакція від 30.07.2010 р. [Електронний ресурс]. — Режим доступу : http://zakon.rada.gov.ua/cgi-bin/laws/main.cgi?nreg=74\%2F98-\%E2\%F0. Заголовок с экрана.

3. Закон України «Про Основні засади розвитку інформаційного суспільства в Україні на 2007-2015 роки» [Електронний ресурс]. - Режим доступу : http://zakon.rada.gov.ua/cgi-bin/laws/main.cgi?nreg=537-16. — Назва з екрану.

4. Розпорядження Кабінету Міністрів та Концепції на веб-сайті Національної бібліотеки України ім. В. І. Вернадського [Електронний ресурс]. — Режим доступу : http://www.nbuv.gov.ua/law/09_bib_21.html. — Назва з екрану.

5. Постанова Кабінету Міністрів України від 17 серпня 2011 р. № 956 «ро затвердження Державної цільової національно-культурної програми створення єдиної інформаційної бібліотечної системи "Бібліотека - XXI" [Електронний ресурс]. Режим доступу : http://zakon2.rada.gov.ua/laws/show/956-2011-\%D0\%BF.

6. Спірін О. М. Проект концепції електронної бібліотеки Національної академії педагогічних наук України [Електронний ресурс] / О.М.Спірін, С. М. Іванова, О.В.Новицький, М. А. Шиненко // Інформаційні технології і засоби навчання. 2010. — № 6 (20). — Режим доступу до журналу : http://www.ime.edu-ua.net/em.html.

7. Спірін О. М. Проектування системи електронних бібліотек науковонавчальних закладів АПН України [Електронний ресурс] / О. М. Спірін, В. М. Саух, В. А. Резніченко, О. В. Новицький // Інформаційні технології і засоби навчання. - 
2009. - № 6(14). - Режим доступу до журн. : http://www.nbuv.gov.ua/ejournals/ITZN/em14/emg.html.

8. Open Archives Initiative [Електронний pecypc]. - Режим доступу : http://www.openarchives.org. - Заголовок з екрану.

\title{
КОНЦЕПТУАЛЬНЫЕ ОСНОВЫ СОЗДАНИЯ СЕТИ ЕЛЕКТРОННЫХ БИБЛИОТЕК НАЦИОНАЛЬНОЙ АКАДЕМИИ ПЕДАГОГИЧЕСКИХ НАУК УКРАИНЫ
}

Спирин Олег Михайлович, доктор педагогических наук, главный научный сотрудник, Институт информационных технологий и средств обучения НАПН Украины, г. Киев, e-mail: Oleg.Spirin@gmail.com

Иванова Светлана Николаевна, научный сотрудник, Институт информационных технологий и средств обучения НАПН Украины, г. Киев, e-mail: iv-svetlana@ yandex.ru Новицкий Александр Вадимович, научный сотрудник, Институт информационных технологий и средств обучения НАПН Украины, г. Киев, e-mail: alex.googl@gmail.com

\section{Аннотация}

В статье определяются предварительные условия проектирования сети электронных библиотек Национальной академии педагогических наук Украины, основные компоненты и базовые сервисы для создания сети электронных библиотек (ЭБ). Анализируются основные подходы к формированию информационных ресурсов ЭБ; выделяются основные организационные основы создания и администрирования ЭБ.

Предлагаются методология наполнения ЭБ ресурсами и подходы по разработке типовых проектных решений для построения ЭБ. Отмечается, что сеть электронных библиотек позволит изменить принцип информационного обслуживания пользователей и по-новому организовать рабочее место ученого.

Ключевые слова: электронная библиотека, сеть электронных библиотек, формирование информационных ресурсов.

\author{
CONCEPTUAL BASIS OF THE NATIONAL ACADEMY OF PEDAGOGICAL \\ SCIENCES OF UKRAINE DIGITAL LIBRARIES NETWORK CONSTRUCTION
}


Oleg M. Spirin, Doctor of Pedagogical Sciences, Chief Researcher, Institute of Information Technologies and Learning Tools of NAPS of Ukraine, Kyiv, e-mail: Oleg.Spirin@ gmail.com Svitlana M. Ivanova, researcher, Institute of Information Technologies and Learning Tools of NAPS of Ukraine, Kyiv, e-mail: iv-svetlana@ yandex.ru

Olexandr V. Novyckiy, researcher, Institute of Information Technologies and Learning Tools of NAPS of Ukraine, Kyiv, e-mail: alex.googl@gmail.com

\section{Resume}

This article indicates the preconditions of the National Academy of Pedagogical Sciences of Ukraine digital libraries network design, the core components and basic services for a digital libraries network (DL). The basic approaches to formation of DL information resources are analyzed, as well as emphasized the major organizational principles for the creation and administration of DL.

There is proposed a methodology for filling of DL by resources and development of typical approaches to design solutions for DL construction. It is noted that a digital libraries network will change the principle information service of users and is a new way to organize a workplace for scientist.

Keywords: digital library, network of digital libraries, formation of information resources. 